The long-run relationship between finance and income inequality: evidence from panel data

John Thornton ab, Caterina Di Tommaso c

a Office of Technical Assistance, US Department of the Treasury, Washington DC, USA

b The Business School, Bangor University, Bangor, UK

c Department of Business Administration and Law, Università della Calabria, Italy.

* Corresponding author. Tel.: +1 202355 8637. Email:

John. Thorntondotatreas.us; j.thorntondbangor.ac.uk

\title{
ABSTRACT
}

We use heterogeneous panel cointegration techniques to examine the long-run effect of financial development on income inequality in a panel of 119 countries from 1980 to 2015. We include real GDP per capita in the cointegration relation and explicitly deal with cross-sectional dependence in the data that arises due to unobserved common factors. On average, financial development reduces income inequality in the long-run, with the result robust to different measures of finance and across country income groups. JEL : D31, D63, F02, O15

Keywords: Income inequality, Financial development, Heterogeneous panel cointegration

Wordcount: 1,918 


\section{The long-run relationship between finance and income inequality: evidence from panel data ${ }^{1}$}

\section{Introduction}

The impact of financial development on income inequality has received a lot of attention, reflecting conflicting theoretical predictions and empirical findings. One set of theoretical models implies that financial development enhances economic growth and reduces income inequality. In these models, financial imperfections (e.g., information and transactions costs) are especially binding on low-income individuals who lack collateral and credit histories and any improvement on the imperfections (reflecting financial deepening) disproportionately benefits them. Furthermore, the financial imperfections reduce the efficiency of capital allocation and intensify income inequality by impeding the flow of capital to low-income individuals with high expected return investments (Aghion and Bolton, 1997; Galor and Zeira, 1993; Galor and Moav, 2004). From this perspective, financial development helps low-income individuals both by improving the efficiency of capital allocation, which accelerates economic growth, and by relaxing credit constraints on the poor, which reduces income inequality. In the same vein, Braun, et al. (2019) develop a model in which broader access to finance as a result of financial deepening moves resources from highly endowed to poorly endowed individuals such that financial deepening reduces the ex post level of income inequality. In contrast, other models predict that financial development primarily helps high income individuals. According to this view, low income individuals rely mainly on informal connections for capital, so that improvements in the

\footnotetext{
${ }^{1}$ We are grateful to an anonymous referee for comments that improved the paper.
} 
formal financial sector mainly benefits those on high incomes. For example, Greenwood and Jovanovic (1990) argue that financial and economic development interact to produce an inverted u-shaped relationship between income inequality and financial development. In their model, financial development improves capital allocation at all stages of development, boosts aggregate growth, and helps the low-income individuals through this channel. However, the distributional effect of financial development depends on the level of economic development. At early stages of development, only the high-income individuals can afford to access and benefit from financial markets, whereas at higher levels of economic development, many more people access financial markets so that financial development directly helps a larger proportion of society and the distribution of income stabilizes.

The empirical evidence on the impact of financial development on income inequality is also inconclusive. For example, Li et al. (1998), Clarke et al. (2006), Beck et al. (2007), Hamori and Hashiguchi (2012) and Naceur and Zhang (2016) report that countries with higher levels of financial development have less income inequality. Kim and Lin (2011) and Law et al. (2014) report a nonlinear relationship, Jaumotte et al. (2013), de Haan and Sturm (2017), and Dabla-Norris et al. (2015) report a positive relationship between finance and income equality, and BahmaniOskooee and Zhang (2015) find mixed results. ${ }^{2}$

In this paper, we revisit the empirical relationship between finance and income inequality making several contributions to the empirical literature. First, we measure financial development

2 See Claessens and Perotti (2007), Demirgüç-Kunt and Levine (2009), de Haan and Sturm (2017) for more detailed reviews of the relevant empirical literature. 
employing an index of financial development developed recently by IMF staff, which is designed to capture the depth, access and efficiency dimensions of financial institutions and financial markets (see Sahay et al., 2015; Svirydzenka, 2016), This contrasts with most other studies that have relied on the ratio to GDP of bank credit or broad money supply as a measure of financial development, both of which reflect narrow banking sector-oriented measures of financial development. For completeness, however, we also report results using the bank credit-to-GDP ratio as a measure of financial development. Second, the mixed results from other studies partly reflects differences in sample size and estimation methodologies that are subject to a variety of estimation problems, including omitted variables, slope heterogeneity, and endogenous regressors. In contrast, we employ a much larger number of countries in our data panel than is typical of other studies, which allows us to examine the effects of finance on income inequality generally as well as across country income groups to shed light on whether the impact of finance depends upon income levels. Third, we employ heterogeneous panel cointegration techniques that are robust to many problems common to standard cross-country and panel regressions (Pedroni, 2007) to examine the long-run effect of financial development on income inequality. We deal with unobserved common factors by incorporating cross sectional averages in the panel data (Pesaran, 2006). Despite the robustness of this cointegration methodology to endogenous regressors and omitted variables, we also include per capita real GDP in the cointegration relation due to its possible importance as a determinant of income inequality in the long-run (see most notably, Kuznets, 1955).

\section{Model and data}


We employ a trivariate cointegration regression involving the Gini coefficient, financial development, and real GDP per capita to assess the long-run impact of financial development on income inequality. We begin by considering a model of the form:

$$
G_{i t}=\alpha_{i}+\delta_{i} t+\beta_{1} F_{i t}+\beta_{2} Y_{i t}+\varepsilon_{i t}
$$

Where $\alpha_{i}$ are country-specific fixed effects and $\delta_{t}$ are country specific time trends included to control for any country-specific omitted factors that are relatively stable over time. $G_{i t}$ is the Gini coefficient over time periods $t=1,2, \ldots ., T$ and countries $i=1,2, \ldots ., N, F_{i t}$ is a measure of financial development and $Y_{i t}$ is the log of real GDP per capita in country. The Gini coefficient is based on households' income before taxes and is from solt's (2009) Standardized World Income Inequality Database (SWIID). To measure financial development, we employ: (i) the index of total financial development $\left(T F D_{i t}\right)$ developed recently by IMF staff, which is designed to capture the depth, access and efficiency dimensions of financial institutions (banks and nonbanks) and financial markets (see Svirydzenka, 2016); (ii) the two key subindices that of the financial development index that reflect separately the contributions from the development of financial institutions $\left(F D I N S_{i t}\right)$ and financial markets (FDMKT $\left.T_{i t}\right)$; and (iii) the more commonly used ratio to GDP of bank credit to the private sector (PCRED $i t)$ (e.g., Levine 2005). GDP per capita (2010 US\$) is from the World Bank's World Development Indicators database. Our panel is unbalanced and comprises annual data for 119 advanced and developing countries for the period 1980-2015.3

3 The countries included in the panel are listed in the appendix where inclusion guided by data availability. 


\section{Results}

We begin by examining the basic time-series properties of the data and then test for the existence of a long-run or cointegrating relationship between $G_{i t}, F_{i t}$, and $Y_{i t}$. To examine the unit root properties of the series we employ the panel unit root test of Im et al. (2003, henceforth IPS). However, as this procedure assumes cross-sectional independence that might lead to spurious inferences if the errors, $\varepsilon_{i t}$, are not independent across $i$, we also consider the cross-sectionally augmented IPS (CIPS) test proposed by Pesaran (2007), which allows for cross-sectional dependence by augmenting the ADF regression with the cross-section averages of lagged levels and first-differences of the individual series (see, e.g., Herzer and Vollmer, 2012; Baltagi and Pesaran, 2007). The results are reported in Table 1 and show that for both the IPS and CIPS tests the null hypothesis cannot be rejected for the level series, while it is rejected for the first differenced seriesi.e., the individual series in Eq. (1) appear to be non-stationary I (1) processes.

We test for cointegration with the panel and group test statistics suggested by Pedroni (1999) and report the Fisher statistic proposed by Maddala and Wu (1999) which follows a $\chi^{2}$ distribution with $2 \times \mathrm{N}$ degrees of freedom. However, as these tests do not account for potential cross-sectional dependence, we follow Francois and Keinsley (2019) and Pedroni (1999) and adopt a residual-based, two-step approach. In addition, we extend the approach with a Common Correlated Effects (CCE) estimation procedure developed by Pesaran (2006) by augmenting the cointegrating regression with the cross-sectional averages of the 
dependent variable and the observed regressors as proxies for the unobserved factors, which takes account of possible crosssectional dependence from unobserved common factors. The second step involves the computation of the CIPS statistic for the residuals from the individual $\mathrm{CCE}$ long-run relations (Baltagi and Pesaran, 2007). The cointegration results are reported in Table 2 and show that under all of these cointegration procedures the null hypothesis of no integration is rejected and the Fisher $\chi^{2}-$ statistics support the existence of at least one cointegrating vector. Accordingly, the results indicate the presence of a longrun relationship between income inequality, financial development (on all measures) and real GDP per capita.

We estimate the long-run growth effect of financial development on income inequality using the between-dimension group-mean panel dynamic ordinary least squares (DOLS) estimator of Pedroni (2001), which allows for greater flexibility in the presence of heterogeneous cointegrating vectors. The panel DOLS regression is given by:

$\operatorname{Gini}_{i t}=\alpha_{i}+\delta_{i} t+\beta_{1 i} F_{i t}+\beta_{2 i} \log \left(Y_{i t}\right)+\sum_{j=-k i}^{k i} \Phi_{1 i j} \Delta F_{i t-j}+\sum_{j=-k i}^{k i} \Phi_{2 i j} \Delta \log \left(Y_{i t-j}\right)+\epsilon_{i t}$

where $\Phi_{1 i j}$ and $\Phi_{2 i j}$ are coefficients of the lead and lag differences that account for potential serial correlation and endogeneity of the regressors. A feature of the DOLS procedure is that it produces unbiased estimates for variables that are cointegrated even in the presence of endogenous regressors. In the case of financial development, there might be reverse causality, for example, if low 
income households were successful in demanding more credit to reduce their consumption disparities with high-income households. For example, Fischer et al. (2019) report panel regression results suggesting that within country increases in income inequality lead to a higher ratio of private credit to GDP in economies with low incomes and weak legal rights, though the effect vanishes and even becomes negative in economies with higher incomes and stronger legal rights. ${ }^{4}$ The group-mean panel DOLS estimator is computed as:

$$
\hat{\beta}_{\mathrm{m}=} N^{-1} \sum_{i=1}^{N} \hat{\beta}_{\mathrm{mi}}
$$

where $\mathrm{m}=1,2$ and $\hat{\beta}_{\mathrm{mi}}$ is the conventional time-series DOLS estimator applied to the ith country of the panel. We account for crosssectional dependence that might be induced by common shocks and/or spillovers among countries by applying the DOLS procedure to the demeaned data.

The DOLS estimates for the coefficients on financial development and real GDP per capita are reported in Table 3 where for completeness we report results for the demeaned and unadjusted data. The coefficients on each measure financial development are negative and statistically significant for both the demeaned and unadjusted data. A one percentage point increase in financial development will induce a reduction in the Gini coefficient by

\footnotetext{
4 We acknowledge-as pointed out by the anonymous referee-that the methodology employed may not completely rule out potential biases associated with reverse causality and other sources of endogeneity bias.
} 
between 0.21 to 1.30 percentage points depending on the measure of financial development in the case of demeaned data, and between 0.92 and 1.75 percentage points in the case of the unadjusted data. In contrast, the coefficient on real GDP per capita is consistently positive and statistically significant and indicate that income inequality increases as countries become richer. This is consistent with greater financial development being a buffer against the tendency for income inequality to increase as countries develop.

Finally, several studies have found that the impact of financial development on income inequality depends in part on the level of development. For example, Altunbaş and Thornton (2019) recently reported that financial development increases income inequality in high- and lower- income countries but promotes greater inequality in upper-middle-income countries. We test whether the long-run effect of financial development on income inequality differs according to income group by re-estimating Eq. (2) for high-income, upper-middle, and lower income countries. ${ }^{5}$ The results from the demeaned series are reported in Table 4. In the case of the total financial development index, $T F D_{i t}$, financial development reduces income inequality for all income groups; for the other measures of finance, the coefficient is either also negative and statistically significant or (mainly for lower income countries) not significant. For each group, income inequality increases with economic growth.

\section{Conclusion}

5 The World Bank's classification scheme for 2015 defined high-income economies are those with a GNI per capita of $\$ 12,476$ or more and upper middle-income economies are those with a GNI per capita between \$4,036 and \$12,475. 
We find that financial development reduces income inequality in the long-run in a panel of 119 countries advanced and developing economies. This result is robust to several measures of financial development and is generally consistent across country income classifications. It is consistent with financial development acting as a buffer against the tendency for income inequality to increase as countries become richer. 


\section{References}

Aghion, P., Bolton, P., 1997. A theory of trickle-down growth and development. Review of Economic Studies, 64, 151-172.

Altunbaş, Y., Thornton, J., 2019. The impact of financial development on income inequality: a quantile regression approach. Economics Letters 175, 51-56.

Bahmani-Oskooee, M., Zhang, R., 2015. On the impact of financial development on income distribution: time-series evidence. Applied Economics 47, 1248-1271.

Baltagi, B.H., Pesaran, M.H., 2007. Heterogeneity and cross section dependence in panel data models: theory and applications introduction. Journal of Applied Econometrics $22, \quad 229-232$.

Beck, T., Demirgüç-Kunt, A., Levine, R., 2007. Finance, inequality and the poor. Journal of Economic Growth 12, 2749 .

Braun, M., Parra, F., Valenzuela, P., 2019. Does finance alter the relation between inequality and growth? Economic Inquiry 57, 410-428.

Claessens, S., Perrotti, E., 2007. Finance and inequality: channels and evidence. Journal of Comparative Economics 35,7 $48-773$.

Clarke, G., Xu, L. C., Zou, H., 2006. Finance and income inequality: what do the data tell us? Southern Economic Journal 72, 578-596.

Dabla-Norris, E., Kochhar, K., Ricka, F., Suphaphiphat, N., Tsounta, E., 2015. Causes and consequences of income inequality: a global perspective. IMF staff Discussion Note $15 / 13$. 
De Haan, J., Sturm, J-E., 2017. Finance and income inequality: a review and new evidence. European Journal of Political Economy 50, 171-195.

Fischer, R., Huerta, D., Valenzuela, P., 2019. The inequalitycredit nexus. Journal of International Money and Finance 91, $105-125$.

Francois, J.N., Keinsley, A., 2019. The long-run relationship between public consumption and output in developing countries: evidence from panel data. Economic Letters 174, 96-99.

Galor, O., Moav, O., 2004. From physical to human capital accumulation: inequality and the process of development. Review of Economic Studies 71, 1001-1026. Galor, O., Zeira, J., 1993. Income distribution and macroeconomics. Review of Economic Studies 60, 35-52. Greenwood, J., Jovanovic, B., 1990.Financial development, growth, and the distribution of income. Journal of Political Economy 98, 1076-1107.

Hamori, S., Hashiguchi, Y., 2012. The effect of financial deepening on inequality: some international evidence. Journal of Asian Economics 23, 353-359.

Hertzer, D., Vollmer, S., 2012. Inequality and growth: evidence from panel cointegration. Journal of Economic Inequality 10, $489-503$.

Im, K.S., Pesaran, M.H., Shin, Y., 2003. Testing for unit roots in heterogeneous panels. Journal of Econometrics 115, 53-74. Jaumotte, F., Lall, S., Papageorgiou, C., 2013. Rising income inequality: technology, or trade and financial globalization? IMF Economic Review 61, 271-309.

Kim, D., Lin, S., 2011. Nonlinearity in the financial development-income inequality nexus. Journal of Comparative Economics 39, 310-325. 
Kuznets, S., 1955. Economic growth and income inequality. American Economic Review 45, 1-28.

Law, S.H., Tan, H.B., Azman-Saini, W.N.W., 2014. Financial development and income inequality at different levels of institutional quality. Emerging Markets Finance \& Trade 50, $21-33$.

Li, H., Squire, L., Zou, H., 1998. Explaining international and intertemporal variations in income distribution. The Economic Journal 108, 26-43.

Levine, R., 2005. Finance and Growth: Theory and Evidence. In: Aghion, P., Durlauf, D. (Eds.), Handbook of Economic Growth. Elsevier Science, The Netherlands, pp. 866-934.

Maddala, G.S., Wu, S., 1999. A comparative study of unit root tests with panel data and a new simple test. Oxford Bulletin of Economics and Statistics 61, 631-652.

Naceur, S.B., Zhang, R., 2016. Financial development, inequality and poverty: some international evidence. IMF Working Paper $16 / 32$.

Pedroni, P., 1999. Critical values for cointegration tests in heterogeneous panels with multiple regressors. Oxford Bulletin of Economics and Statistics 61 (S1), 653-670.

Pedroni, P., 2001. Purchasing power parity tests in cointegrated panels. Review of Economics and Statistics 83, 727-731. Pedroni, P., 2007. Social capital, barriers to production and capital shares: implications for the importance of parameter heterogeneity from a nonstationary panel approach. Journal of Applied Economics 22, 429-451.

Pesaran, M.H., 2006. Estimation and inference in large heterogeneous panels with a multifactor error structure. Econometrica 74, 967-1012. 
Pesaran, M.H., 2007. A simple panel unit root test in the presence of cross-section dependence. Journal of Applied Econometrics 22, 265-312.

Solt, F, 2009. Standardizing the world income inequality database. Social Science Quarterly 90, 231-242.

Svirydzenka, K., 2016. Introducing a New Broad-based Index of Financial Development IMF Working Paper No. 16/5. 
Table 1

Panel unit roots tests.

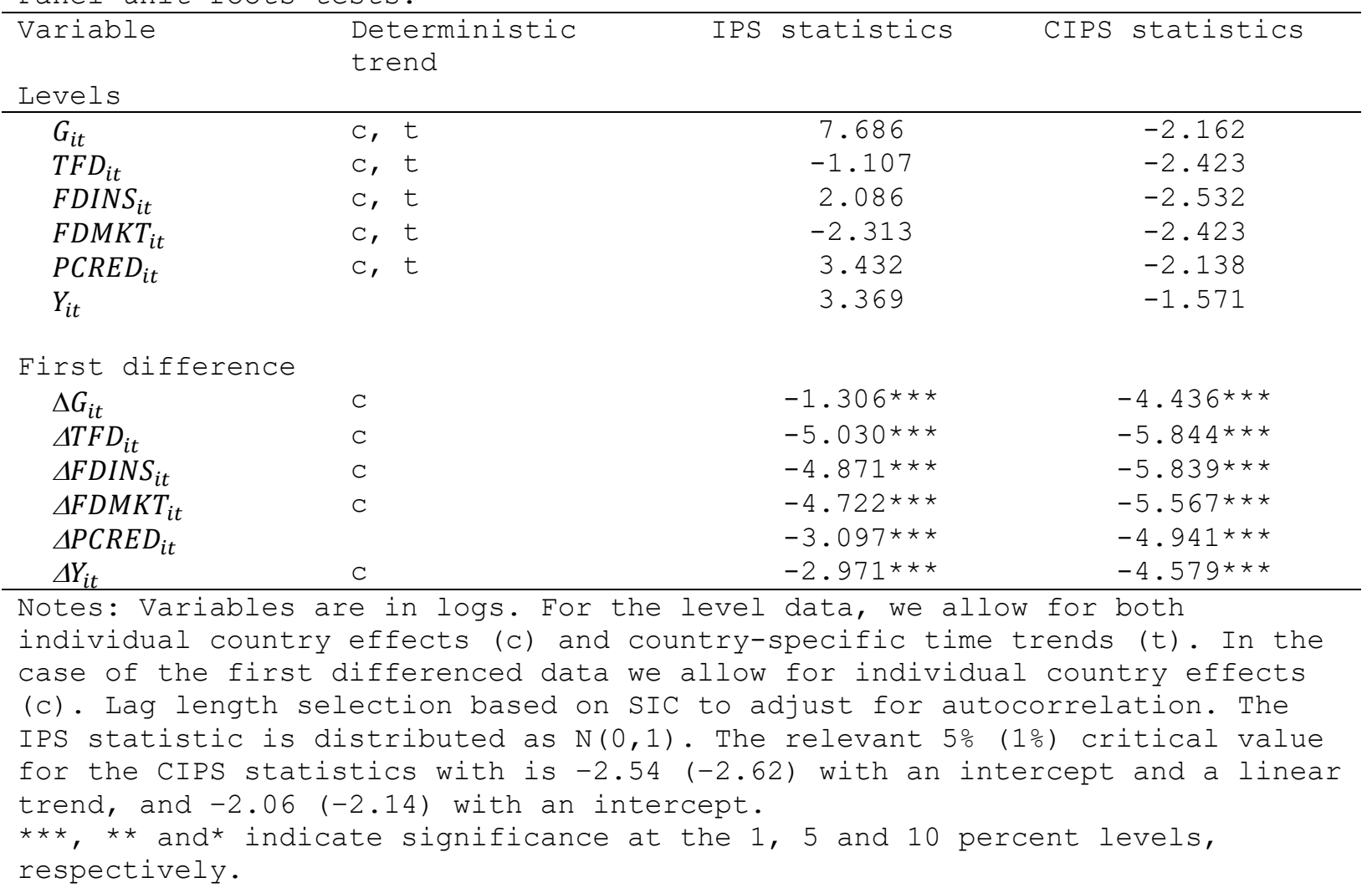


Table 2

Panel cointegration tests.

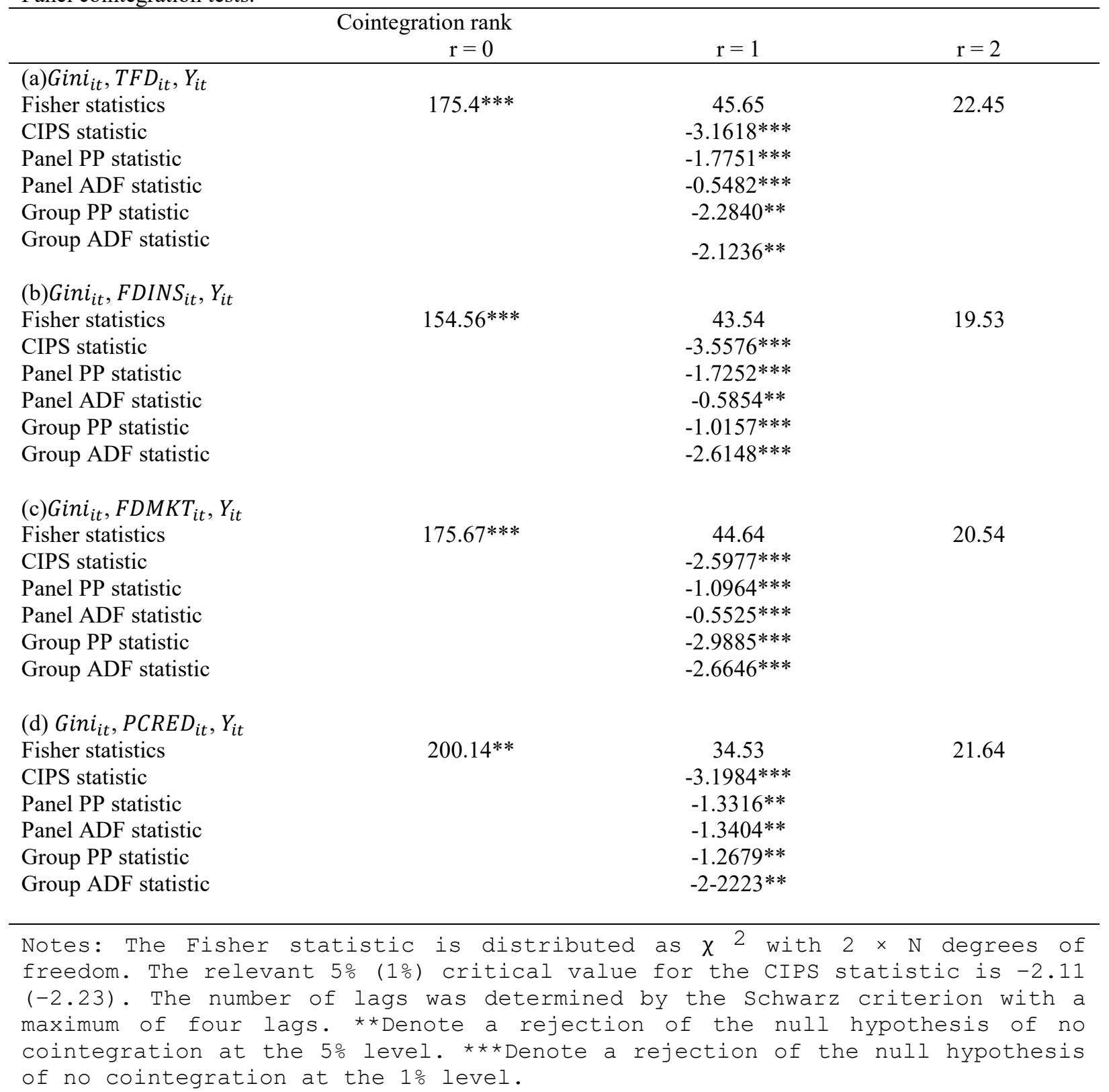




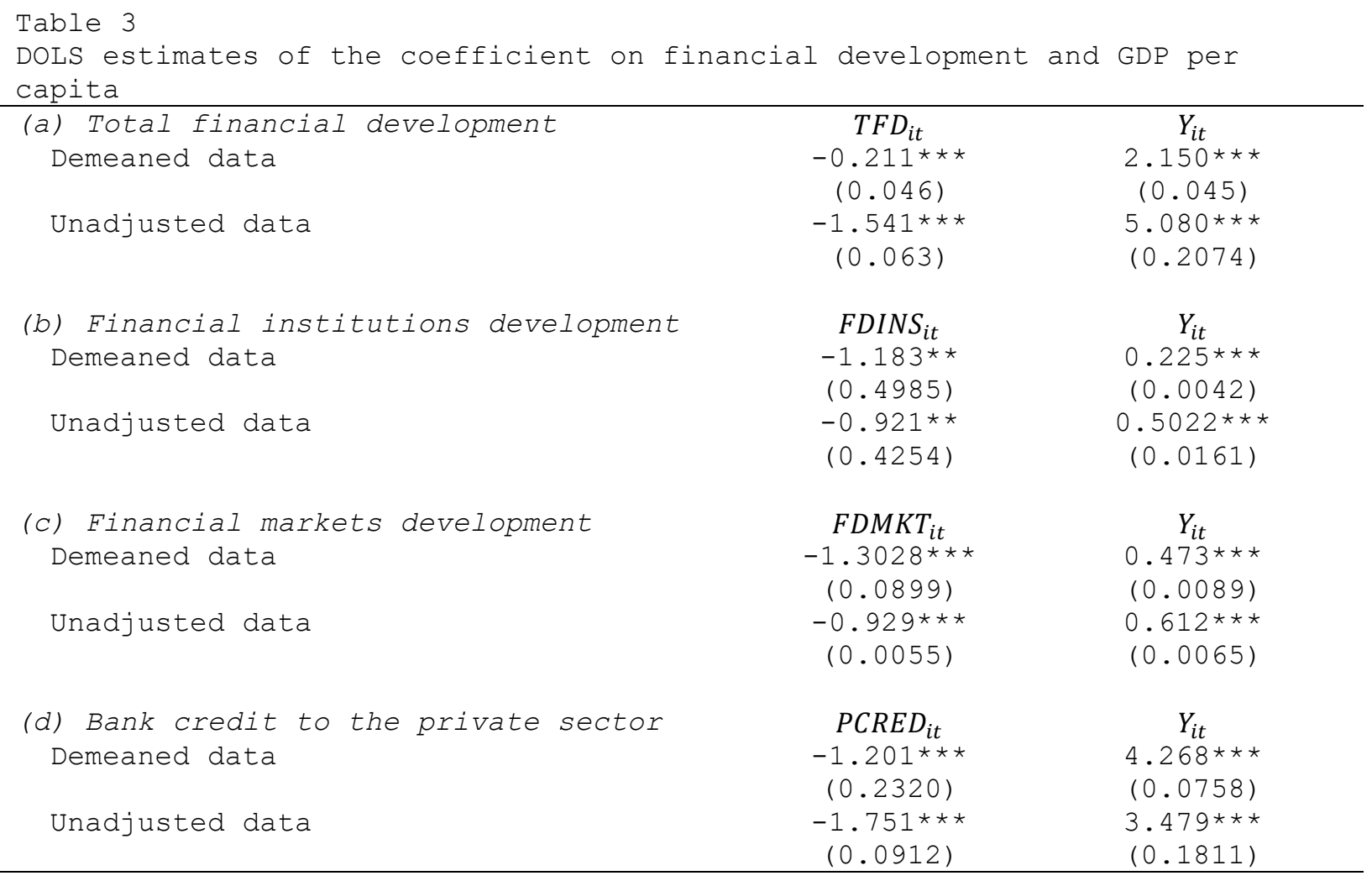

Notes: Variables are in logs. The dependent variable is $G_{i t}$. Standard errors in parentheses. The number of leads and lags in the individual DoLS regressions was determined by the Schwarz criterion with a maximum of three lags. The unadjusted data assumes cross-section independence. $\star \star \star$ Indicates significance at the 1 percent level. 
Table 4

DOLS estimates for countries by income group (demeaned series)

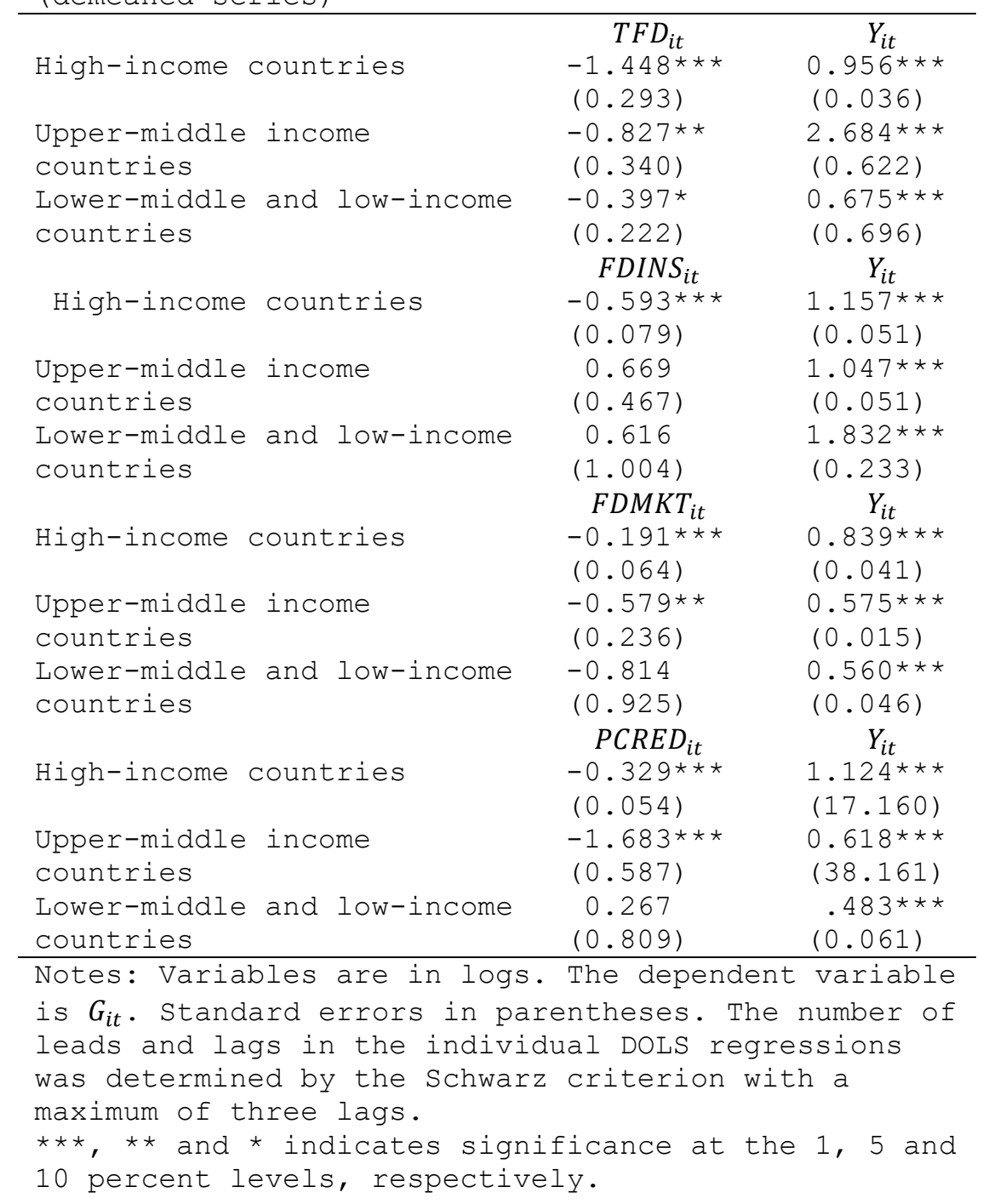




\section{Appendix}

Countries in the sample

High-income:

Australia, Austria, Barbados, Belgium, Canada, Chile, Croatia, Czech Republic, Denmark, Finland, France, Germany, Greece, Hong Kong, Hungary, Iceland, Ireland, Israel, Italy, Japan, Korea, Latvia, Lithuania, Luxembourg, Netherlands, New Zealand, Norway, Poland, Portugal, Singapore, Slovak Republic, Slovenia, Spain, Sweden, Switzerland, Trinidad and Tobago, United Kingdom, United States, and Uruguay.

Upper-middle income:

Albania, Algeria, Argentina, Azerbaijan, Belarus, Botswana, Brazil, Bulgaria, China, Colombia, Costa Rica, Dominican Republic, Ecuador, Fiji, Georgia, Guyana, Iran, Jamaica, Jordan, Kazakhstan, Lesotho, Macedonia, Malaysia, Mauritius, Mexico, Namibia, Panama, Paraguay, Peru, Romania, Russia, South Africa, Thailand, Turkey, and Venezuela.

Lower-income:

Armenia, Bangladesh, Bolivia, Burkina Faso, Burundi, Cameroon, Central African Republic, Cote d'Ivoire, Egypt, El Salvador, Estonia, Ethiopia, Ghana, Guatemala, Guinea-Bissau, Haiti, Honduras, India, Indonesia, Kenya, Kyrgyz Republic, Madagascar, Malawi, Mali, Moldova, Mongolia, Morocco, Mozambique, Nepal, Nicaragua, Niger, Nigeria, Pakistan, Papua New Guinea, Philippines, Rwanda, Senegal, Sierra Leone, Sri Lanka, Tanzania, Tunisia, Uganda, Ukraine, Vietnam, and Zambia.

Note: Countries classified according to the World Bank's 2015 income classification system. Lowerincome includes low-income and lower-middle income classifications. 